\title{
Efektivitas Media Pembelajaran Terhadap Prestasi Belajar Matematika Siswa Kelas XI SMA Negeri 10 Mataram
}

\author{
Septia Hariyanti ${ }^{*}$, Arjudin ${ }^{2}$, Baidowi $^{3}$ \\ ${ }^{1}$ Mahasiswa Pendidikan Matematika, FKIP, Universitas Mataram, Mataram \\ 2,3 Dosen Pendidikan Matematika, FKIP, Universitas Mataram, Mataram \\ *email: hseptia916@gmail.com
}

\begin{abstract}
This research aims to: (1) Describe learning achievement in mathematics of students at class XI SMA Negeri 10 Mataram after media of learning was applied and (2) know the effectiveness of the media learning towards achievement of students in mathematics at class XI SMA Negeri 10 Mataram academic year 2019/2020. The type of this research was designed using one of the forms of pre-experimental design that was one shot case study. The subject of this research were students of XI SMA Negeri 10 Mataram which consisted of 112 students, where XI MIPA 2 as experimental class. The results of those data were obtained by giving post-test to the experiment class. Analysis data included descriptive analysis and inferential analysis of test by using one sample right tailed t test to know the effectiveness of the learning media to students' mathematics learning achievement. The results showed that 13 students were higher than MMC (Minimum Mastery Criteria) and belong to good category with $61.9 \%, 8$ students were lower than MMC and belong to less category with $38.1 \%$, and no one student got very less category or $0 \%$. Data analysis results were concluded that media of learning was effective on the learning achievement in mathematics of students at class XI SMA Negeri 10 Mataram academic year 2019/2020.
\end{abstract}

Keywords: Effectiveness; Media; Achievement; Mathematics Learning

\begin{abstract}
Abstrak
Negeri 10 Mataram setelah diterapkan media pembelajaran dan (2) mengetahui efektivitas media pembelajaran terhadap prestasi belajar matematika siswa kelas XI SMA Negeri 10 Mataram tahun ajaran 2019/2020. Jenis penelitian eksperimen ini dirancang dengan menggunakan salah satu bentuk desain penelitian pre-experimental design yaitu oneshot case study. Subjek penelitian ini adalah siswa kelas XI SMA Negeri 10 Mataram yang berjumlah 112 siswa, di mana kelas XI MIPA 2 sebagai kelas eksperimen. Pengambilan data dilakukan dengan pemberian post-test kepada kelas eksperimen. Analisis data meliputi analsisis deskriptif dan analisis inferensial dengan uji t satu sampel pihak kanan untuk mengetahui efektivitas penggunaan media pembelajaran terhadap prestasi belajar matematika siswa. Hasil penelitian menunjukkan bahwa 13 siswa memiliki nilai di atas KKM (Kriteria Ketuntasan Minimum) berada pada kategori baik dengan persentase 61,9\%, 8 siswa memiliki nilai di bawah KKM berada pada kategori kurang dengan persentase $38,1 \%$, dan tidak ada siswa berada pada kategori sangat kurang karena memiliki persentase $0 \%$. Hasil penelitian dapat disimpulkan bahwa media pembelajaran efektif terhadap prestasi belajar matematika siswa kelas XI SMA Negeri 10 Mataram tahun ajaran 2019/2020.
\end{abstract}

Kata Kunci: Efektivitas; Media; Prestasi; Belajar Matematika

\section{PENDAHULUAN}

Kondisi saat ini yang biasa ditemui dalam dunia pendidikan khususnya pada mata pelajaran matematika adalah munculnya prasangka negatif. Pelajaran yang didominasi angka-angka ini kerap membuat siswa mengerutkan dahi dan kesulitan dalam 


\section{Mandalika Mathematics and Education Journal \\ Volume 3 Nomor 1, Juni 2021 \\ e-ISSN 2715-1190| | p-ISSN 2715-8292 \\ DOI: http://dx.doi.org/10.29303/jm.v3i1.2275}

menghadapinya. Terlebih lagi objek matematika yang abstrak, dan materi dalam pelajaran matematika tidak mudah dipahami mengurangi minat siswa dalam belajar.

Lebih lanjut berdasarkan hasil observasi dengan melakukan wawancara kepada siswa selama mengikuti Program Pengalaman Lapangan (PPL) di kelas X SMA Negeri 10 Mataram sebagian besar siswa menyatakan bahwa matematika merupakan pelajaran yang sulit karena banyak rumus dan hitungan jadinya membosankan dan tidak menyenangkan. Hal ini tentu saja berdampak negatif terhadap prestasi belajar siswa. Permasalahan ini menjadi bahan pertimbangan bagi guru untuk lebih meningkatkan kualitas pembelajaran dalam mengurangi stigma negatif siswa dalam belajar matematika.

Peran guru menuju pendidikan abad 21 dituntut untuk meningkatkan profesionalisme. Pernyataan tersebut menegaskan bahwa proses pembelajaran yang bermakna merupakan inti dari proses pendidikan dengan guru sebagai pemegang peranan utama. Hal itu pula yang menjadi tugas cukup berat bagi guru dalam mengelola kelas. Kegiatan pembelajaran menuntut dikuranginya metode ceramah dan diganti dengan pemakaian media pembelajaran yang tentu diharapkan dapat mempertinggi kualitas hasil belajar siswa. Penggunaan media dapat mengefektifkan kegiatan pembelajaran dan membantu siswa menyerap pelajaran lebih cepat. Namun, fakta di lapangan menunjukkan bahwa penggunaan media dalam proses pembelajaran matematika masih jarang dilakukan. Apalagi SMA Negeri 10 Mataram merupakan SMA yang baru beroperasi pada tahun 2018. Berdasarkan hasil wawancara dengan guru mata pelajaran matematika menyatakan penggunaan media pembelajaran hanya buku paket siswa yang ada di perpustakaan sekolah saja. Kondisi ini menyebabkan siswa menjadi pasif, cepat bosan, dan materi pelajaran yang disampaikan guru sulit untuk dipahami oleh siswa sehingga prestasi belajar siswa menurun. Hal tersebut juga diperkuat oleh data nilai ulangan umum matematika semester ganjil kelas X SMA Negeri 10 Mataram yang tergolong rendah yaitu banyak siswa yang belum mencapai Kriteria Ketuntasan Minimal (KKM) yang telah ditetapkan sebesar 75 sehingga nilai siswa secara rata-rata belum mencapai KKM dan memiliki nilai ketuntasan klasikal di bawah $85 \%$. Suatu kelas dikatakan tuntas belajarnya (ketuntasan klasikal) jika dalam kelas tersebut terdapat $\geq 85 \%$ siswa yang tuntas belajarnya (Trianto, 2010). Data tersebut disajikan dalam tabel 1 berikut.

Tabel 1. Nilai Ulangan Harian Matematika Semester Ganjil Kelas X SMA Negeri 10 Mataram

\begin{tabular}{cccccc}
\hline No. & Kelas & $\begin{array}{c}\text { Jumlah } \\
\text { Siswa }\end{array}$ & $\begin{array}{c}\text { Nilai } \\
\text { Rata-Rata }\end{array}$ & KKM & $\begin{array}{c}\text { Ketuntasan } \\
\text { Klasikal }\end{array}$ \\
\hline 1. & X MIPA 1 & 24 & 70,21 & 75 & $50,00 \%$ \\
\hline 2. & X MIPA 2 & 21 & 68,19 & 75 & $19,05 \%$ \\
\hline 3. & X IPS 1 & 24 & 50,42 & 75 & $4,17 \%$ \\
\hline 4. & X IPS 2 & 22 & 55,36 & 75 & $4,55 \%$ \\
\hline
\end{tabular}




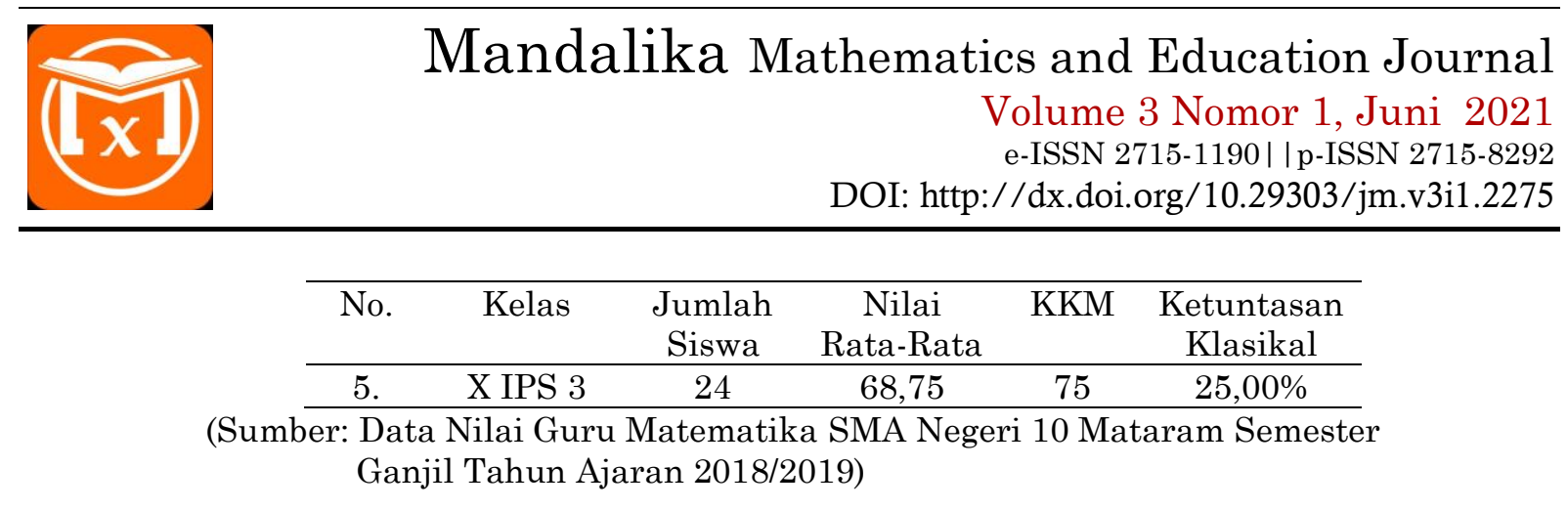

Di dalam mengatasi permasalahan ini, dianggap penting untuk menerapkan pembelajaran baru yang mampu mengoptimalkan prestasi belajar matematika siswa melalui penggunaan media pembelajaran yang lebih bervariasi tidak hanya berpaku pada buku paket sehingga berpotensi menjadi salah satu solusi inovatif terhadap kemajuan prestasi belajar matematika siswa. Media pembelajaran yang digunakan dalam penelitian ini adalah media visual. Materi yang dipilih adalah program linier dua variabel karena merupakan materi yang dekat dengan kehidupan sehari-hari. Model pembelajaran yang dapat digunakan yaitu Direct Instruction atau lebih dikenal dengan pembelajaran langsung. Model Direct Instruction diperlukan suatu media pembelajaran visual dalam sintaksnya yang dapat mempertinggi proses dan hasil pembelajaran karena melalui media pembelajaran hal-hal yang abstrak dapat dikongkretkan, dan hal-hal yang kompleks dapat disederhanakan (Sudjana dan Rivai, 2010).

Berdasarkan latar belakang tersebut maka dilakukanlah penelitian dengan judul "Efektivitas Media Pembelajaran terhadap Prestasi Belajar Matematika Siswa Kelas XI SMA Negeri 10 Mataram Tahun Ajaran 2019/2020". Di dalam tampilnya media pembelajaran yang mempunyai makna bagi siswa dalam menumbuhkan kembali perhatian belajar siswa serta guru dapat memotivasi siswa dalam belajar.

\section{METODE}

Jenis dari penelitian ini adalah penelitian eksperimen dengan menggunakan media pembelajaran visual. Pendekatan yang digunakan dalam penelitian ini yaitu pendekatan kuantitatif. Teknik pengambilan sampel yang digunakan adalah purposive samping karena pada sampel karakteristiknya sudah ditentukan dan diketahui lebih dulu berdasarkan ciri dan sifat populasinya. Berdasarkan teknik sampling yang digunakan sampel yang diambil adalah kelas XI MIPA 2 yang terdiri dari 21 siswa. Penelitian ini menggunakan desain penelitian pre-experimental design dengan rancangan penelitian one shot case study. Instrumen yang digunakan pada penelitian ini adalah tes berupa soal-soal uraian. Uji instrumen yang digunakan adalah uji validitas dan uji reliabilitas. Setelah dilakukan penelitian, data yang diperoleh kemudian dianalisis dengan menggunakan statistik analisis deskriptif dan statistik analisis inferensial.

a. Analisis Deskriptif

Adapun langkah-langkah yang ditempuh dalam analisis deskriptif prestasi belajar siswa setelah diterapkan media pembelajaran LKS dan Slides PowerPoint sebagai berikut. 
1) Menentukan skor maksimal ideal dan skor minimal ideal

Skor maksimal $=100$

Skor minimal $=0$

2) Menentukan nilai Mean Ideal $\left(M_{i}\right)$

$$
\begin{aligned}
M_{i} & =\frac{1}{2}(\text { skor maksimal }+ \text { skor minimal }) \\
& =\frac{1}{2}(100+0) \\
& =50
\end{aligned}
$$

3) Menentukan nilai simpangan baku ideal $\left(S b_{i}\right)$

$$
\begin{aligned}
S b_{i} & =\frac{1}{6}(\text { skor maksimal }- \text { skor minimal }) \\
& =\frac{1}{6}(100-0) \\
& =16,7
\end{aligned}
$$

4) Menentukan kriteria penafsiran

Penentukan kriteria penafsiran kemampuan siswa dimodifikasi menjadi lima kriteria yang tersaji pada tabel 2 berikut (Ekawati dan Sumaryanta, 2011).

Tabel 2. Kriteria Penafsiran

\begin{tabular}{cc}
\hline Interval Skor & Kriteria \\
\hline$X \geq M_{i}+1,5 S b_{i}$ & Baik Sekali \\
$M_{i}+0,5 S b_{i} \leq X<M_{i}+1,5 S b_{i}$ & Baik \\
$M_{i}-0,5 S b_{i} \leq X<M_{i}+0,5 S b_{i}$ & Sedang \\
$M_{i}-1,5 S b_{i} \leq X<M_{i}-0,5 S b_{i}$ & Kurang \\
$X<M_{i}-1,5 S b_{i}$ & Kurang Sekali \\
\hline
\end{tabular}

5) Menentukan kriteria penafsiran

Berdasarkan interval skor yang sudah diperoleh, kriteria penafsiran dengan mempertimbangkan KKM (75) akan dibagi menjadi tiga kategori kemampuan siswa yang disajikan pada tabel 3 berikut.

Tabel 3. Pengkategorian Hasil Post-Test Siswa

\begin{tabular}{cc}
\hline Interval Skor & Kategori \\
\hline$X \geq 75,05$ & Baik \\
\hline $58,35 \leq X<75,05$ & Kurang \\
\hline $41,65 \leq X<58,35$ & \\
$24,95 \leq X<41,65$ & Sangat kurang \\
$X<24,95$ & \\
\hline
\end{tabular}

b. Analisis Inferensial

Statistik inferensial yang digunakan adalah uji t satu sampel pihak kanan. Untuk keperluan uji hipotesis, terlebih dahulu diadakan uji prasyarat dengan melakukan uji normalitas data. Uji normalitas dicari dengan menggunakan rumus uji Liliefors. Selanjutnya, pengujian hipotesis dapat dilihat melalui nilai ketuntasan klasikal dan 
nilai rata-rata siswa. Ditinjau dari nilai ketuntasan klasikal kelas eksperimen berdasarkan nilai ulangan harian matematika sebelumnya memperoleh ketuntasan klasikal sebesar 19,05\% sangat jauh di bawah ketuntasan klasikal ideal yaitu $85 \%$. Sehingga pengujian hipotesis di dalam penelitian ini ditinjau dari nilai rata-rata ulangan harian matematika sebelumnya yaitu 68,19. Rumus uji t yang digunakan yakni rumus uji t satu sampel pihak kanan (Sugiyono, 2008).

$$
t_{\text {hitung }}=\frac{\bar{x}-\mu_{0}}{\frac{s}{\sqrt{n}}}
$$

dengan simpangan baku $\mathrm{s}=\sqrt{\frac{\sum_{i=1}^{n}\left(x_{i}-\bar{x}\right)^{2}}{n-1}}$, nilai $t_{\text {hitung }}$ akan dikonsultasikan dengan $t_{\text {tabel }}$ dengan derajat kebebasan $(d k)=n-1$ dan taraf signifikansi yang digunakan adalah $5 \%$ dengan kriteria pengujian yaitu, jika $t_{\text {hitung }} \leq t_{\text {tabel }}$ maka $H_{o}$ diterima dan sebaliknya jika $t_{\text {hitung }}>t_{\text {tabel }}$ maka $H_{o}$ ditolak.

\section{HASIL DAN PEMBAHASAN}

\subsection{Hasil Penelitian}

\section{a. Hasil Analisis Deskriptif}

Data nilai kelas sampel eksperimen dapat dilihat dari nilai post-test siswa pada tabel 4 sebagai berikut.

Tabel 4. Data Post-Test Siswa

\begin{tabular}{cccccccc}
\hline KKM & $\begin{array}{c}\text { Jumlah } \\
\text { Siswa }\end{array}$ & \multicolumn{6}{c}{ Hasil Penelitian Post-Test Siswa } \\
\cline { 3 - 8 } & $\begin{array}{c}\text { Nilai } \\
\text { Tertinggi }\end{array}$ & $\begin{array}{c}\text { Nilai } \\
\text { Terendah }\end{array}$ & Tuntas & $\begin{array}{c}\text { Tidak } \\
\text { Tuntas }\end{array}$ & $\begin{array}{c}\text { Jumlah } \\
\text { Nilai }\end{array}$ & $\begin{array}{c}\text { Rata- } \\
\text { rata }\end{array}$ \\
\hline 75 & 21 & 100 & 68 & 13 & 8 & 1677 & 79,86 \\
\hline
\end{tabular}

Dari tabel 4 di atas dapat diketahui bahwa dari 21 siswa yang mengikuti post-test, rata-rata seluruh siswa adalah 79,86 dan secara rata-rata melampaui KKM yaitu 75 karena siswa yang tuntas lebih banyak dibandingkan banyak siswa yang tidak tuntas. Lebih jelasnya berikut data hasil post-test siswa dalam bentuk diagram yang dapat dilihat pada gambar 1 berikut. 


\section{Mandalika Mathematics and Education Journal}

Volume 3 Nomor 1, Juni 2021

e-ISSN 2715-1190 | | p-ISSN 2715-8292

DOI: http://dx.doi.org/10.29303/jm.v3i1.2275

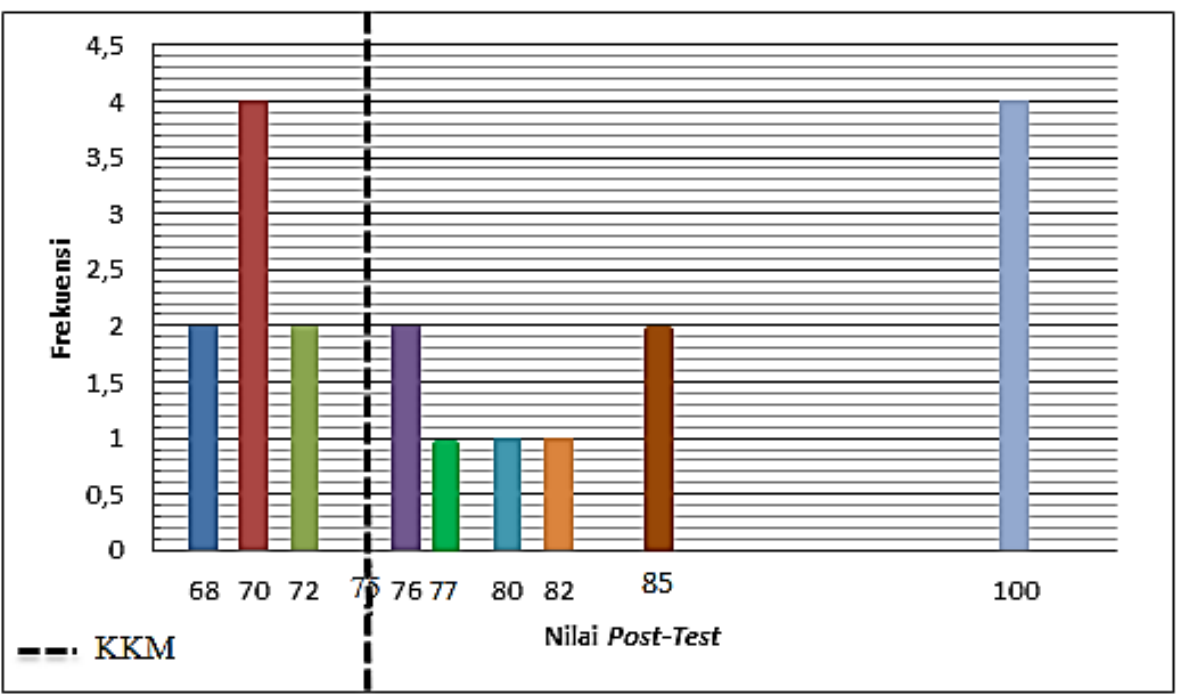

Gambar 1. Diagram Frekuensi Nilai Post-Test Siswa

Gambar 1 yang disajikan berupa diagram di atas menunjukkan bahwa 8 siswa dinyatakan tidak tuntas karena memiliki nilai di bawah KKM sedangkan 13 siswa dinyatakan tuntas karena memiliki nilai di atas KKM yaitu 75. Sedangkan data kelas sampel dilihat dari ketuntasan klasikal nilai ulangan harian matematika semester ganjil tahun 2018/2019 siswa dengan ketuntasan klasikal hasil post-test siswa pada tabel 5 berikut.

Tabel 5. Perbandingan Ketuntasan Klasikal Ulangan Harian Matematika dengan Data Hasil Post-Test

\begin{tabular}{ccc}
\hline Kelas & $\begin{array}{c}\text { Ketuntasan Klasikal } \\
\text { Ulangan Harian Matematika }\end{array}$ & $\begin{array}{c}\text { Ketuntasan Klasikal Hasil } \\
\text { Post-Test }\end{array}$ \\
\hline Eksperimen & $19,05 \%$ & $61,9 \%$ \\
\hline
\end{tabular}

Tabel 5 di atas menunjukkan perubahan yang terjadi dari ketuntasan klasikal ulangan harian matematika semester ganjil yaitu 19,05\% dengan data hasil post-test siswa setelah diterapkan media pembelajaran mencapai $61,9 \%$.

Berdasarkan interval skor yang sudah diperoleh, kriteria penafsiran dengan mempertimbangkan KKM (75) akan dibagi menjadi tiga kategori yaitu $\geq$ 75 berkategori baik dan $<75$ berkategori kurang, dan sangat kurang. Hasil kriteria penafsiran berdasarkan nilai KKM disajikan pada tabel 6 di bawah ini.

Tabel 6. Pengkategorian Hasil Post-Test Siswa

\begin{tabular}{cccc}
\hline Interval Skor & Frekuensi & Persentase & Kategori \\
\hline$X \geq 75,05$ & 13 & $61,9 \%$ & Baik \\
\hline $58,35 \leq X<75,05$ & 8 & $38,1 \%$ & Kurang \\
\hline
\end{tabular}




\section{Mandalika Mathematics and Education Journal}

Volume 3 Nomor 1, Juni 2021

e-ISSN 2715-1190 | | p-ISSN 2715-8292

DOI: http://dx.doi.org/10.29303/jm.v3i1.2275

\begin{tabular}{cccc}
\hline Interval Skor & Frekuensi & Persentase & Kategori \\
\hline $41,65 \leq X<58,35$ & & & \\
$24,95 \leq X<41,65$ & 0 & $0 \%$ & Sangat Kurang \\
$X<24,95$ & & & \\
\hline
\end{tabular}

Berdasarkan tabel 6 di atas dapat diketahui bahwa pengkategorian berdasarkan hasil post-test, 13 siswa memiliki nilai di atas KKM berada pada kategori baik dengan persentase $61,9 \%, 8$ siswa memiliki nilai di bawah KKM pada kategori kurang dengan persentase $38,1 \%$, dan tidak ada siswa berada pada kategori sangat kurang karena memiliki persentase $0 \%$. Lebih jelasnya berikut analisis deskripsi kemampuan siswa mengerjakan post-test dalam bentuk histogram yang dapat dilihat pada gambar 2 berikut.

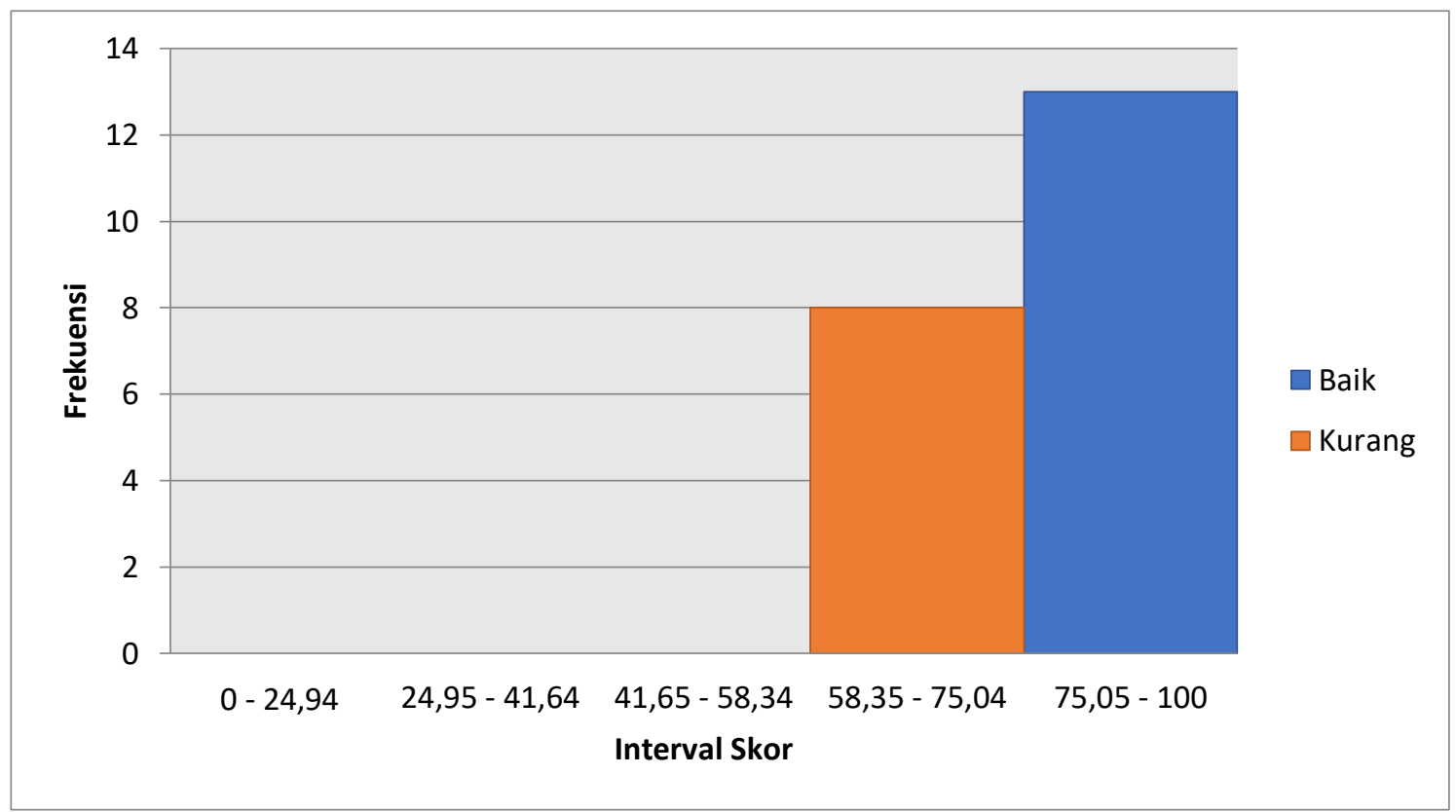

Gambar 2. Histogram Pengkategorian Hasil Post-Test Siswa

Gambar 2 yang disajikan dalam histogram di atas menunjukkan bahwa kemampuan siswa kelas eksperimen berada pada kategori baik yaitu 13 siswa dan kategori kurang yaitu 8 siswa.

\section{b. Hasil Analisis Inferensial}

Data prestasi belajar siswa yang diperoleh diolah dengan menggunakan analisis statistik yaitu analisis statistik uji t satu sampel pihak kanan. Sebelum menggunakan analisis statistik uji t maka terlebih dahulu dilakukan uji normalitas data kemudian uji hipotesis. 


\section{1) Uji Normalitas}

Adapun analisis uji normalitas hasil post-test kelas eksperimen dapat dilihat pada tabel 7 sebagai berikut.

Tabel 7. Hasil Uji Normalitas

\begin{tabular}{ccccc}
\hline \multirow{2}{*}{ Kelas } & $\begin{array}{c}\text { Taraf } \\
\text { Signifikans } \\
\mathrm{i}\end{array}$ & $L_{\text {hitung }}$ & $L_{\text {tabel }}$ & Kesimpulan \\
\hline Eksperimen & $5 \%$ & 0,18477 & 0,1881 & $\begin{array}{c}\text { Berdistribusi } \\
\text { normal }\end{array}$ \\
\hline
\end{tabular}

Dari tabel 7 diketahui bahwa hasil post-test setelah diberikan media pembelajaran diperoleh $L_{\text {hitung }}=0,18477$ dan $L_{\text {tabel }}=0,1881$. Hal ini menunjukkan bahwa $L_{\text {hitung }}=$ $0,163146<L_{\text {tabel }}=0,1881$. Sehingga pada taraf signifikansi $5 \%$ dan $L_{\text {hitung }}<L_{\text {tabel }}$, maka data nilai post-test siswa berdistribusi normal.

\section{2) Uji Hipotesis}

Secara ringkas hasil uji statistik menggunakan uji t satu sampel pihak kanan berdasarkan hipotesis dapat dilihat pada tabel 8 berikut.

Tabel 8. Hasil Uji t Data Prestasi Belajar Matematika Siswa

\begin{tabular}{|c|c|c|c|c|c|c|}
\hline Kelas & $\begin{array}{c}\text { Nilai rata- } \\
\text { rata } \\
\text { ulangan } \\
\text { harian } \\
\text { matematika }\end{array}$ & $\begin{array}{c}\text { Nilai } \\
\text { rata-rata } \\
\text { hasil } \\
\text { post-test }\end{array}$ & $t_{\text {hitung }}$ & $t_{\text {tabel }}$ & $\begin{array}{c}\text { Derajat } \\
\text { kebebasan } \\
(\mathrm{dk})\end{array}$ & Kesimpulan \\
\hline Eksperimen & 68,19 & 79,86 & 4,76 & 1,72 & 20 & $\mathrm{H}_{0}$ ditolak \\
\hline
\end{tabular}

Berdasarkan tabel 8 diperoleh nilai rata-rata data awal yaitu 68,19 dan nilai ratarata hasil post-test adalah 79,86. Pada taraf signifikansi $5 \%$ diperoleh $t_{\text {hitung }}=4,76$ dan $t_{\text {tabel }}=1,72$. Nilai $t_{\text {hitung }}$ dikonsultasikan dengan $t_{\text {tabel }}$ dengan derajat kebebasan $(\mathrm{dk})=n-1=(21-1=20)$ dan taraf signifikansi yang digunakan adalah $5 \%$. Dari hasil perhitungan diperoleh bahwat $t_{\text {hitung }}=4,76>t_{\text {tabel }}=1,72$. Karena $t_{\text {hitung }}>$ $t_{\text {tabel }}$, ini berarti bahwa $\mathrm{H}_{0}$ ditolak dan $\mathrm{H}_{\mathrm{a}}$ diterima.

Hasil pengujian ini memberikan kesimpulan $\mathrm{H}_{\mathrm{a}}$ diterima. Pengambilan keputusan ini berlaku bahwa nilai rata-rata hasil post-test kelas eksperimen lebih dari nilai ratarata ulangan harian matematika kelas ekperimen yang menunjukkan bahwa terdapat perbedaan nilai rata-rata hasil post-test kelas eksperimen setelah diberikan media pembelajaran. Terjadi peningkatan yang signifikan nilai rata-rata hasil posttest kelas eksperimen menunjukkan bahwa media pembelajaran efektif terhadap prestasi belajar matematika siswa kelas XI SMA Negeri 10 Mataram tahun ajaran 2019/2020. 


\subsection{Pembahasan}

Penelitian ini merupakan penelitian eksperimen yang bertujuan untuk mendeskripsikan prestasi belajar matematika siswa setelah diterapkan media pembelajaran dan mengetahui efektivitas media pembelajaran terhadap prestasi belajar matematika siswa kelas XI SMA Negeri 10 Mataram tahun ajaran 2019/2020. Media pembelajaran yang digunakan adalah media visual berupa lembar kerja siswa (LKS) dan slides PowerPoint yang diterapkan pada materi program linier dua variabel dengan menggunakan model pembelajaran Direct Instruction. Pada penelitian ini kelas XI MIPA 2 dipilih sebagai kelas sampel eksperimen untuk diterapkan media pembelajaran LKS dan slides PowerPoint.

Pada pelaksanaannya, peneliti melakukan lima kali pertemuan yang diantaranya empat pertemuan untuk proses pembelajaran dengan menggunakan LKS dan slides PowerPoint dan satu kali pertemuan digunakan untuk melakukan post-test. Pelaksanaan pembelajaran pada kelas XI MIPA 2 menggunakan model pembelajaran Direct Instruction dengan metode diskusi, tanya jawab, dan penugasan.

Pelaksanaan pembelajaran di kelas pada saat penelitian berlangsung diawali dengan menampilkan slides PowerPoint untuk membantu guru menjelaskan tujuan pembelajaran, memberikan motivasi dan apersepsi, dan mempersiapkan siswa dalam belajar. Selanjutnya, melalui slides PowerPoint, guru mendemonstrasikan keterampilan atau menyajikan informasi tahap demi tahap untuk membimbing siswa memahami materi yang akan diajarkan yaitu program linier dua variabel dengan terlebih dahulu menjelaskan sistem pertidaksamaan linier dua variabel. Kemudian, guru mengorganisasikan siswa menjadi 5 kelompok di mana tiap-tiap kelompok terdiri dari 4 sampai 5 orang. Setelah siswa berkumpul dengan kelompoknya, selanjutnya guru memberikan latihan terbimbing dengan membagikan LKS kepada siswa untuk lebih memahami konsep yang diajarkan guru. Tiap pertemuan guru memberikan LKS yang berbeda kepada siswa. Tiap LKS mengandung suatu masalah kontekstual yang dekat dengan kehidupan sehari-hari.

Berdasarkan analisis deskriptif prestasi belajar matematika siswa setelah diterapkan media pembelajaran, dari 21 siswa yang mengikuti post-test, rata-rata seluruh siswa kelas sampel adalah 79,86. Deskripsi berdasarkan kemampuan siswa dalam post-test dengan mempertimbangkan KKM (75) dibagi menjadi tiga kategori yaitu $\geq$ 75 berkategori tinggi, < 75 berkategori kurang, dan sangat kurang. Hasil pengkategorian berdasarkan nilai KKM, 13 siswa memiliki nilai di atas KKM berada pada kategori tinggi dengan persentase $61,9 \%$, 8 siswa memiliki nilai di bawah KKM berada pada kategori kurang dengan persentase $38,1 \%$, dan 0 siswa berada pada kategori sangat kurang atau dapat dikatakan tidak ada siswa yang berada pada kategori sangat kurang dengan persentase $0 \%$.

Sedangkan analisis inferensial digunakan untuk mengetahui efektivitas prestasi belajar siswa setelah diterapkan media pembelajaran. Hasil pengujian ini memberikan kesimpulan $\mathrm{H}_{\mathrm{a}}$ diterima. Pengambilan keputusan ini berlaku bahwa nilai rata-rata hasil 


\section{Mandalika Mathematics and Education Journal \\ Volume 3 Nomor 1, Juni 2021 \\ e-ISSN 2715-1190| | p-ISSN 2715-8292 \\ DOI: http://dx.doi.org/10.29303/jm.v3i1.2275}

post-test kelas eksperimen lebih dari nilai rata-rata data awal kelas ekperimen yang menunjukkan bahwa terdapat perbedaan rata-rata hasil post-test siswa setelah diterapkan media pembelajaran terhadap prestasi belajar matematika siswa kelas XI SMA Negeri 10 Mataram tahun ajaran 2019/2020. Terjadi peningkatan yang signifikan nilai rata-rata hasil post-test menunjukkan media pembelajaran efektif terhadap prestasi belajar matematika siswa kelas XI SMA Negeri 10 Mataram tahun ajaran 2019/2020.

Hasil penelitian ini sejalan dengan penelitian yang dilakukan Faizah dan Astutik (2017) menunjukkan bahwa dengan adanya LKS guru lebih terbantu dalam pelaksanaan pembelajaran dan LKS efektif dalam pembelajaran matematika pada materi Program Linier. Penayangan slides PowerPoint bertujuan untuk memvisualisasikan LKS yang dibagikan oleh guru dan sebagai bantuan guru untuk menjelaskan kepada siswa. Sehingga di dalam penelitian ini, media slides PowerPoint khusus untuk memperjelas konsep yang diajarkan guru. Ditinjau dari alokasi waktu, di dalam penelitian ini pelaksanaannya dilakukan sebanyak 5 kali pertemuan atau 10 jam pelajaran lebih kecil dari alokasi waktu pembelajaran yang biasa digunakan dalam sekolah yaitu 8 kali pertemuan atau 16 jam pelajaran. Sehingga media pembelajaran dapat dikatakan efektif dari segi hasil dan waktu.

Namun, ketuntasan klasikal siswa belum memenuhi ketuntasan klasikal ideal yaitu 85\%. Hal ini dikarenakan kondisi SMA Negeri 10 Mataram yang merupakan salah satu sekolah yang beroperasi di tahun 2018, dengan kata lain sekolah mulai menerima siswa baru di tahun 2018 dan belum memiliki banyak pengalaman dalam bidang prestasi akademik. Berdasarkan hasil wawancara dengan 8 siswa yang nilainya di bawah KKM, rata-rata siswa menjawab faktor internal sebagai alasan nilai tidak mencapai KKM. Faktor internal yang mempengaruhi prestasi belajar siswa adalah minat dan motivasi belajar siswa yang kurang seperti adanya rasa malas belajar, tidak berminat dalam belajar matematika, tidak suka, tidak paham dengan materi, dan mengantuk. Oleh karena itu, guru berupaya untuk memberikan banyak latihan soal kepada siswa untuk meningkatkan prestasi belajar siswa. Selain latihan soal, hal lain yang dapat dilakukan adalah dengan menggunakan media pembelajaran untuk membantu siswa dalam meningkatkan prestasi belajar salah satunya dengan menggunakan media pembelajaran LKS dan slides PowerPoint.

\section{PENUTUP}

Berdasarkan data hasil penelitian dan pembahasan, dapat disimpulkan bahwa nilai ratarata hasil post-test siswa mencapai 79,86. Deskripsi kemampuan siswa dalam post-test setelah diberikan media pembelajaran dengan mempertimbangkan KKM (75), 13 siswa memiliki nilai di atas KKM berada pada kategori baik dengan persentase 61,9\%, 8 siswa memiliki nilai di bawah KKM berada pada kategori kurang dengan persentase $38,1 \%$, 
dan tidak ada siswa berada pada kategori sangat kurang karena memiliki persentase $0 \%$. Media pembelajaran efektif terhadap prestasi belajar matematika siswa kelas XI SMA Negeri 10 Mataram tahun ajaran 2019/2020. Hal ini dapat dilihat dari nilai rata-rata hasil post-test kelas eksperimen lebih dari nilai rata-rata ulangan harian matematika kelas ekperimen sebelumnya sehingga terdapat perbedaan nilai rata-rata hasil post-test yang menunjukkan kelas eksperimen mengalami peningkatan yang signifikan setelah diberikan media pembelajaran.

\section{REFERENSI}

Ekawati, E., \& Sumaryanta. (2011). Pengembangan instrumen penilaian pembelajaran matematika SD/SMP. Yogyakarta: Pusat Pengembangan dan Pemberdayaan Pendidik Tenaga Kependidikan (PPPPTK) Matematika.

Faizah, H., \& Astutik, E. P. (2017). Efektivitas lembar kerja siswa (LKS) berbantuan software geogebra pada materi program linier. Jurnal Pendidikan Matematika dan Matematika, 3(2), 108. http://jurnal.umj.ac.id/index.php/fbc/article/view/2109.

Sudjana, N., \& Rivai, A. (2010). Media pengajaran. Bandung: Sinar Baru Algensindo.

Sugiyono. (2008). Metode penelitian kuantitatif kualitatif dan R\&D. Bandung: Alfabeta.

Trianto. (2010). Mendesain model pembelajaran inovatif-progresif: konsep, landasan, dan implementasinya pada kurikulum tingkat satuan pendidikan (KTSP). Jakarta: Kencana Prenada Media Group. 